\title{
The Determinant Factors of Purchase Intention in the Culinary Business in Indonesia That Mediated by Parasocial Interaction and Food Vlogger Credibility
}

\author{
Lilian Pinda $^{\text {a }}$, Kenji Handoko ${ }^{b}$, Sandy Halim ${ }^{c}$, Willy Gunadi ${ }^{\text {d }}$ \\ a, b, c,d Business Management Program, Management Department, BINUS Business School Master Program, Bina Nusantara \\ University, Jakarta, Indonesia, 11480
}

Article History: Received: 10 November 2020; Revised 12 January 2021 Accepted: 27 January 2021; Published online: 5 April 2021

\begin{abstract}
This study aims to analyze the relationship between physical attractiveness, attitude homophily, social attractiveness, openness, interactivity, credibility, parasocial interaction, and purchase intention on YouTube in the culinary business in Indonesia. This research is a causal research design that applies the Structural Equation Modeling (SEM) research model as a method of data analysis. Using convenience sampling, the study sample involved 202 respondents as YouTube users in Jakarta and its surroundings who watched food review content by food vloggers more than three times a month. Based on the results of the hypothesis test, the factors that influence social interaction are physical attractiveness, social attractiveness, and interactivity. Meanwhile, only physical attractiveness affects food vlogger credibility. Therefore, before deciding to collaborate with a food vlogger, marketers can understand how credibility is formed and the interaction between a food vlogger and its audience on social media so that it can influence the audience's buying interest
\end{abstract}

Keywords: Social Media, culinary business, parasocial interaction, food vlogger credibility, purchase intention

\section{Introduction}

Social media has become an important part of everyday life for most Indonesians. The ease of internet access in Indonesia supports the growth of social media users; this can be seen from the number of social media users in Indonesia, which reaches 160 million users or around $60 \%$ of Indonesia's total population (Wearesocial Hootsuite, 2020). There are four most active social media platforms in Indonesia, namely YouTube, WhatsApp, Facebook, and Instagram (Wearesocial Hootsuite, 2020). Among the four most actively used social media in Indonesia, YouTube is the most used social media, $88 \%$ of the total population of social media users (Wearesocial Hootsuite, 2020). YouTube is one of the best social media platforms today for advertising, watching videos, reviews, and tutorials (Razak \& Zulki y, 2020). YouTube is the best medium for audiences to convey their feelings and messages through facial expressions and communication skills. YouTube has a longer duration and has various content to offer to entertain and satisfy its audiences (Ferman \& Champman, 2017). Also, a product review on YouTube looks more real and attracts the attention of audiences to buy (Razak \& Zulkifly, 2020). The number of YouTube channels with more than one million subscribers in Indonesia continues to grow every day (Jonathan, 2019). This shows great interest in the emergence of the vlogger trend in Indonesia. Vloggers are YouTube social media influencers who make journalistic documentation videos that contain the lifestyle, thoughts, and interests of each individual, information, and reviews about the products they use (Master, 2015). The vloggers that we often mention usually have certain preferences used as references in developing content on their profiles. Some focus on fashion, beauty, travel, culinary, and technology (Klassen, Borleis, Brennan, Reid, McCaffrey, Lim, 2018).

This research will focus on culinary vloggers, which are often referred to as food vloggers because this research will be conducted on the culinary business in Indonesia. The food and beverage business is a potential industry as a means of economic equality. This can be seen from the very rapid development of the culinary business, as disclosed by the Indonesian Creative Economy Agency (2019), noting that the culinary sub-sector has a contribution of $41 \%$ of the total contribution of Indonesia's creative economy, this number is the highest compared to the business sector. other. The growth of Indonesia's culinary business is increasing and one of the factors of this increase is due to technological advances, namely the emergence of online delivery services, social media, and food vloggers (Febriyantoro \& Arisandi, 2018). However, food and beverage product innovation breakthroughs that continue to develop every year create uncertainty about culinary business trends and consumer appetite for consumption. So, it is difficult to accurately predict consumer demand because changes in trends in the culinary business are very fast, encouraging consumers to continue to try every new culinary trend that is currently busy. Therefore, marketers need to make the right marketing strategies and investments by collaborating with food vloggers to improve relationships with customers, create brand awareness, and increase consumer desire to buy their products (Chang, Peng, \& Berger, 2018). 
Before deciding to collaborate with a food vlogger, marketers need to understand how a food vlogger builds credibility and builds interactions with followers on social media so that it can influence the audience's buying interest. However, research on food vloggers and important factors affecting food vlogger credibility and parasocial interaction as marketing tools in the culinary business sector is still limited. Research on parasocial interaction on social media is mostly in the beauty business sector (Lee \& Watkins,2016), fashion (Kefi \& Sokovia,2018), and travel (Sooyoung, Insin Kim, Kyungsoo, Yongkun, \& Kim,2019). Collaborating with food vloggers is an effective strategy on social media (Ward,2017). Because the video documentation made by food vloggers on their YouTube channel in the form of stories about opinions, reviews, feelings, and culinary information can shape opinions and influence the attitudes and behavior of the audience (Tinaprilla, Sumarwan \& Hermanda, 2019). Also, food vloggers have significant strength because they have a large following, so their influence can create advocacy, change referrals, and purchase an interest in their followers. Moreover, products recommended by vloggers on social media have a higher level of trust than products recommended by family or friends. It is proven that $40 \%$ of consumers buy products that are used and recommended by food vloggers (Tinaprilla et al., 2019).

In improving relationships with followers as a reliable source of information, the role of food vloggers can influence audience preferences and increase purchase intentions that are built and built through credibility and parasocial interactions (Kefi \& Sokolova, 2018). A food vlogger builds credibility and parasocial interaction through physical attractiveness because it is an important instrument in credibility assessment, affecting the first impression that appears when a media user sees it (Rushworth \& Djafarova, 2017). Having an attractive appearance, good life, and conspicuous consumption through videos published on the YouTube channel can increase audience confidence in increasing audience confidence in the credibility of information conveyed by food vloggers (Wathen \& Burkell, 2002). Having attitude homophily, such as similarities in thoughts and behavior between vloggers and their audience, such as having the same education, belief, and social status with the audience, can instill confidence in the products or services promoted by the food vlogger (Lee and Watkins, 2016). Because the audience is more easily influenced by food vloggers who have many similarities, they feel that they are experiencing the experience that food vloggers feel. Thus, the more similarities in the attitude homophily the audience feels with the food vlogger will increase credibility, the audience's desire to interact and participate in activities carried out by food vloggers (Eyal \& Rubin, 2003). Also, audiences usually like vloggers based on their assessment as seen from their positive behavior and the large number of friends they have, because the personality of a food vlogger is what they consider socially attractive if they have a large number of followers and have a community. The social relationships that generate this attraction can affect the level of interaction between food vloggers and their audiences on social media (Lee \& Watkins, 2016).

Currently, the relationship between food vloggers and their audiences on social media is no longer a one-way relationship because audiences and food vloggers can interact through sharing, re-posting, commenting, or discussion of content uploaded by food vloggers (Brown, 2015), and influencers can reply comments from the audience (Kefi \& Sokolova, 2018). Therefore, a food vlogger must have fast and efficient interactivity in interacting with the audience because this will make the audience feel heard. Thus, the audience does not feel that only they pay attention to the vlogger, but they feel cared for and feel that they interact directly with the food vlogger (Labrecque, 2014). Content published by food vloggers can enhance the relationship between food vloggers and their audiences to feel that food vloggers are a reliable source of information (Lee \& Watkins, 2016). The openness of information about culinary provided by food vloggers, such as the latest culinary delights, the taste of food and drinks that are reviewed, is very necessary because the presentation of information about a product can form a positive perception of trust in building relationships and interacting with audiences on social media. Openness in presenting information is very important because the openness of information shared by vloggers to their audience can increase social media interaction (Labrecque, 2014). However, Kefi \& Sokolova's research (2018) previously only examined three factors that influence parasocial interaction: physical attractiveness, homophily, and social attractiveness. This study will add two other factors that can influence parasocial interactions: interactivity and openness (Labrecque, 2014). Therefore, this study aims to analyze the relationship between physical attractiveness, homophilia, social attractiveness, openness and interactivity, the credibility of food vloggers, para-social interactions, and purchase intentions on YouTube in the culinary business in Indonesia. 


\section{Literatur Review}

\subsection{Social Media \& Social media Influencer}

The phenomenon of the emergence of social media is one of the innovations caused by scientific and technological advances; in academic literature, social media is defined as an internet site or application based on interactions between users or content created by social media users (Kaplan \& Haenlein, 2010). Meanwhile, according to research by Garret (2009), social media is a tool and software that can be used to connect individuals to share information. Social media is one of the most frequently used media by most Indonesians to learn, find new information, and share information with their friends (Chang, Peng, \& Berger, 2018). This can be seen from the number of social media users in Indonesia, reaching 150 million users or around $56 \%$ of Indonesia's total population (Wearesocial Hootsuite, 2019). The most active social media platform in Indonesia is YouTube, accounting for $88 \%$ of the total number of social media users in Indonesia (Wearesocial Hootsuite, 2019). Many active users of YouTube social media in Indonesia have led to the growth of the number of YouTube channels, with more than one million subscribers increasing (Jonathan, 2019). This shows great interest in the emergence of the vlogger trend in Indonesia. Vloggers are YouTube social media influencers who make journalistic documentation videos containing each individual's lifestyle, thoughts, and interests, information, and reviews about the products they use (Master, 2015). Vloggers, which we often refer to, usually have certain preferences used as references in developing content in their pro les. Some focus on fashion, beauty, travel, culinary, and technology (Klassen et al., 2018). This research will focus on culinary vloggers, which are often referred to as food vloggers. Food vloggers are YouTube social media influencers who make journalistic documentation videos containing culinary information (Tinaprilla et al., 2019).

\subsection{Purchase Intention}

Purchase intention is important in marketing. Purchase intention can be interpreted as someone's desire to purchase again when the opportunity arises (Tariq, Nawaz, Nawaz \& Butt, 2013). According to Kotler (2009), purchase intention is an impulse that arises in a person to purchase goods and services to meet needs. Purchase intention can also be de ned as the possibility for consumers to buy products or services in the future (Wu, Yeh, \& Hsiao, 2011). Purchase interest comes from the level of value that has been felt before someone makes a final purchase decision, where consumers will consciously or unconsciously compare the benefits they expect from products with the expected costs for their purchase (Morwitz, 2014).

\subsection{Parasocial Interactions}

Parasocial interaction is described as the audience's and player's correlation and typically occurs as a one-way relationship, whereby, usually, the player is known by the audiences, but not the other way around (Horton \& Wohl, 1956). For example, this relationship is like the relationship between the audience and figures in the media, such as celebrities, news anchors, or fictional characters (Rubin \& McHugh, 1987). However, in the development of parasocial interaction, it has evolved to more than a one-way relationship as media gures could better interact with users through sharing, re-posting, commenting, or discussing the uploaded contents (Brown, 2015). In marketing, parasocial interaction is described as the interaction of consumers with media figures (influencers), where consumers feel part of a media figure (Kefi and Sokolova, 2018). Content exposure published by influencers could impact the rise of interaction between social media users and influencers, resulting in influencers perceived to be trustworthy sources of information, and their advice impacts the decision to purchase (Lee \& Watkins, 2016). Therefore, this study formulates a hypothesis, namely:

\section{H1: Parasocial interactions have a positive effect on purchase intentions.}

\subsection{Credibility}

According to Rushworth \& Djafarova (2017), credibility is the extent to which the target audience sees the influencer as having expertise, knowledge, and understanding of the products and services that the influencer reviews on social media. Credibility is linked to the audiences' perceived opinion on communication quality, which impacts the audience's internalization process: shared values and attitudes between followers and influencers (Kefi \& Sokolova, 2018). The credibility of an influencer can also be called the level of trust people have in the influencer (Wathen \& Burkell, 2002). Trust will relate to the perception of the honesty of the influencer, and goodwill can reflect positive responses about an influencer, so that in general, if an influencer is considered trustworthy, attractive, and is considered an expert, it will be ables influence the attitudes and behavior of followers towards purchasing a product (Gunawan \& Huarng, 2015). The level of knowledge and level of trust in an influencer is important things that determine the credibility of an influencer and can influence the process of determining the purchase of a product (Hui, 2017). Research conducted by Fan \& Miao (2012) shows that the credibility of an influencer on social media has a positive effect on purchase intentions. Therefore, this study formulates a hypothesis, namely: 


\section{H2: Credibility has a positive effect on purchase intention.}

\subsection{Physical Attractiveness}

Physical attractiveness is an important instrument that can influence and direct customer behavior (Onu et al., 2019). Influencers who are physically attractive when used as marketing tools will result in better acceptance from consumers of an advertisement (Till \& Busler, 2000). Physical attractiveness is a combination of characteristics that consumers will evaluate whether a food vlogger is beautiful or handsome, the appearance used is attractive or not at all attractive (Aronson, Wilson, \& Akert, 2013). Physical attractiveness is defined as customer identification of some special traits of in uencers they value, such as charisma, personal qualities, beauty or good looks, and athletic posture (Onu et al., 2019). Khamis \& Welling (2016) show that physical attractiveness is an important factor in becoming a famous social media influencer. The audience will see everything displayed in the video uploaded by the food vlogger on their YouTube Channel. For example, the appearance of the food vlogger, the form of the food that is uploaded, the situation in which to eat, and others. The physical attractiveness of a food vlogger is the rst thing the audience pays attention to (Cohen, 2011). The first impression that appears in the mind of the audience regarding the physical attractiveness of a vlogger will affect the assessment of credibility (Wathen $\&$ Burkell, 2002). Having an attractive appearance, good life, and conspicuous consumption through pictures and videos published on social media such as clothes, make-up, food, and holidays can increase trust in influencer credibility (Khamis \& Welling 2016). The interest in the food vlogger's personality who has physical attractiveness can predict parasocial interactions (Lee \& Watkins, 2016). Physical attractiveness is a determinant of parasocial interaction (Giles, 2002). The interaction between the audience and the food vlogger is built from several factors, namely how audience users perceive food vloggers, look physically attractive, and have similarities with them (Lee \& Watkins, 2016). Therefore, this study formulates a hypothesis, namely:

\section{H3: Physical Attractiveness has a positive effect on credibility.}

\section{H4: Physical Attractiveness has a positive effect on parasocial.}

\subsection{Attitude Homophily}

Homophily is the tendency for a person to interact with other people who have the same beliefs, education, and social status (Eyal \& Rubin, 2003). Homophily can also be interpreted as an individual's tendency to make friendly relationships with other individuals who have something in common (Lee \& Watkins, 2016). Meanwhile, according to McPherson, Lovin \& Cook (2001), homophily is that those with the same demographic background will have the same experiences, values, and attitudes. Likewise, Roth (2004) found that attitude homophily is a person's tendency to communicate with individuals who have similar demographics. This attitude homophily is formed through food vloggers who share reviews of food or places to eat. The process of sharing his thoughts is also an indication of the credibility of the uploaded content (Kefi \& Sokolova, 2019). In the context of social media, when there are many similarities between a food vlogger and his followers, the audience's assessment of credibility increases (Wang, Wather, Pingree, \& Hawkins, 2008). Influencers who have similarities with their followers can instill con dence and trust in the product or service being promoted. Based on social cognitive theory, humans will more easily trust and be influenced by public figures who have many similarities with them (Bandura, 1994).

On social media, attitude homophily is formed through influencers who share their thoughts about a product or service. The process of sharing his thoughts is also an indication of the credibility of the uploaded content (Kefi \& Sokolova, 2019). Attitude homophily is a determinant of parasocial interaction on social media because the more level of equality that is felt between the audience and the vlogger, the more interaction between the audience and the vlogger on social media (Giles, 2002; Eyal and Rubin, 2003). Homophily will increase people's desire to experience the experiences or activities of the characters being watched. The more similarities between individuals, the more frequent interactions will occur (Eyal \& Rubin, 2003). The more similarities that are felt by the audience towards food vloggers on social media, the more frequent interactions will be (Lee \& Watkins, 2016). The continuous interaction between the audience and the food vlogger will increase the occurrence of parasocial interactions. Therefore, this study formulates a hypothesis, namely:

H5: Attitude Homophily has a positive effect on credibility.

H6: Attitude Homophily has a positive effect on parasocial interaction. 


\subsection{Social Attractiveness}

The social attractiveness of influencers on social media is assessed based on profile photos and other people's comments and the number of followers on their social media accounts (Wise, Kim, Tandoc \& Hong, 2012). Therefore, social attractiveness can be defied as the impression seen by the audience that an influencer who has high social attractiveness is based on a large number of friends or followers on his social media account (Wise et al., 2012). Social attractiveness is defined as a person's desire to approach other people, based on their assessment as seen from their positive behavior and the large number of friends they have. Meanwhile, according to Lee \&Watkins (2016), social attractiveness is defined as identifying the audience towards the personality of an influencer that they consider socially attractive if they have a large number of friends and have a community. The attraction that occurs between the audience and the food vlogger can be caused by the activity of watching a video or vlog that is repeated so that there is intense interaction and can lead to parasocial interactions (Kefi and Sokolova, 2019). Audiences tend to watch food vlogger videos that are considered to have interesting traits and behavior. According to Lee and Watkins's (2016) research, the more attractive a food vlogger's personality on social media will make audiences feel that they have the same beliefs. The personality of a food vlogger is considered socially attractive if it has many followers and a community (Dewi \& Anike, 2013). Food vloggers who have social appeal by having a large number of followers can affect the level of interaction with audiences who previously had low interest in content or topic. Also, the social attractiveness of influencers (food vloggers) makes the audience feel part of a friendship. It can also increase the interaction between food vloggers and their audience on social media (Kefi and Sokolova, 2019). Therefore, this study formulates a hypothesis, namely:

\section{H7: Social attractiveness has a positive effect on parasocial interaction.}

\subsection{Interactivity}

McMillan \& Hwang (2002); Song \& Zinkhan (2008) defines interactivity as a perceptual variable, where the determining variables of interactivity are the speed of response and the ability to communicate messages. According to Song \& Zinkhan (2008), interactivity is specifically defined as the dependency of users on two-way communication with media personalities. In this sense, the term interactivity not only focuses on website and social media features, but also on messages' content and cues that appear in the content generated, which is used to create the perception that the power of listening and interacting with an important audience (Labrecque, 2014). Influencers who have high interactivity will make their followers feel listened to and feel they are interacting directly (Labrecque, 2014). Social media users do not feel that they are the only ones who pay attention to in uencers, but they will also generate feelings of being cared for by influencers (Hartmann \& Goldhoorn, 2011). Labrecque (2014) indicates that the degree of influencer's interactivity would positively impact the parasocial interactions. Therefore, this study formulates a hypothesis, namely:

\section{H8: Interactivity has a positive effect on parasocial interaction.}

\subsection{Openness}

According to Oswald, Clark, \& Kelly (2004), openness and closeness to satisfaction in friendship can form a positive perception of trust. Similar to friendship in building relationships and interactions with consumers on social media, it has a close relationship with trust and openness used to present reliable information (Sweetser \& Metzgar, 2017; Labrecque, 2014). According to Labrecque (2014), openness is openness in presenting information to consumers or audiences on social media platforms. Openness or openness is what forms a relationship. In this context, the disclosure of culinary information from a food vlogger to his followers. The openness given by a food vlogger is seen in how they provide reviews and information to their followers (Sweet \& Metzgar, 2017). According to Oswald, Clark, \& Kelly (2004), openness and closeness to satisfaction in friendship can form a positive perception of trust. Similar to friendship in building relationships and interactions with audiences on social media, it has a close relationship with trust and openness, which is used to present reliable information (Sweet \& Metzgar, 2017; Labrecque, 2014). Openness is an important factor in social interaction on social media because openness will encourage the formation of parasocial interactions (Labrecque, 2014). Therefore, this study formulates a hypothesis, namely:

\section{H9: Openness has a positive influence on parasocial interaction.}




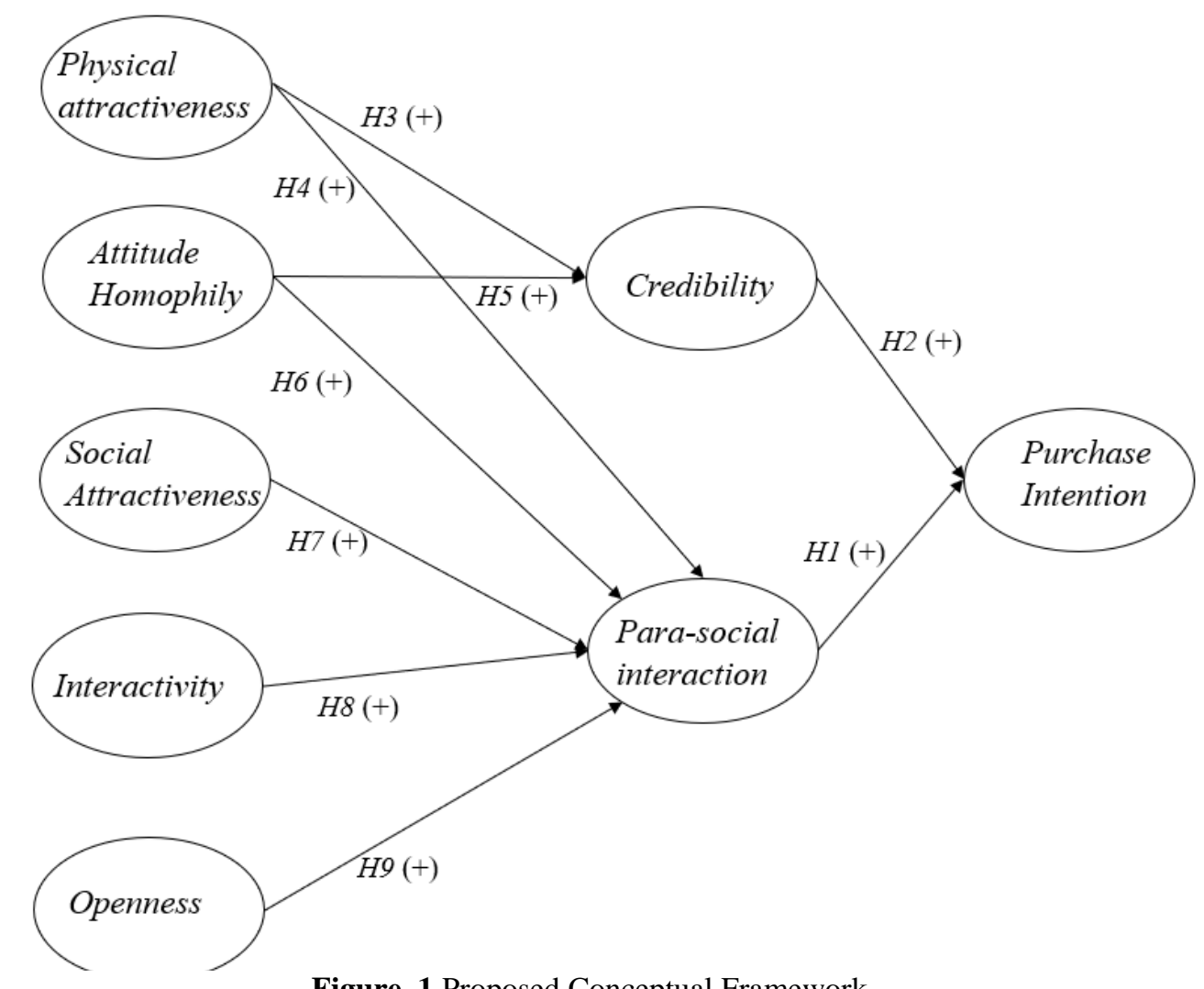

\section{Research Methods}

\subsection{Measurement}

The questionnaire in this study was designed in three parts. First, respondents are asked two screening questions, namely whether the respondent has ever watched a food review video by a food vlogger on YouTube and how often they watched a video about a food review by a food vlogger on YouTube. Second, respondents who have watched video reviews by food vloggers and frequently watched food review videos by food vloggers more than three times a month will be asked general questions regarding demographic questions and measure the behavior of watching food review videos provide their perceptions. On the behavior of watching food review videos by food vloggers, namely, how much time on average you spend watching food reviews in a day, who is your favorite food vlogger, where do you nd out what food vlogger is and what food review content you like. Finally, focus on the questions displayed on a Likert scale (see Appendix 1). There are nine variables involved, measured using a 5-point Likert scale; physical attractiveness is measured by three items (Lee \& Watkins, 2016). Social attractiveness is measured by three items (Lee \& Watkins, 2016). Attitude homophily is measured by five items (Lee \& Watkins, 2016). Interactivity was measured by four items (Labrecque, 2014). Openness is measured by three items (Labrecque, 2014). Credibility is measured by four items (Kefi \& Sokolova, 2019). Parasocial interaction is measured by seven items (Lee \& Watkins, 2016; Kefi \& Sokolova, 2019). Purchase intention is measured by five items (Lee \& Watkins, 2016; Kefi \& Sokolova, 2019).

\subsection{Data Collections \& Analysis}

In this study, the sampling technique used the judgmental sampling method. Data is taken from members of the population that can be accessed easily by researchers, and samples are taken based on criteria formulated in advance by the researcher (Sekaran \& Bougie, 2013). The criteria used are the frequency of respondents who watch culinary review videos on YouTube, with a minimum frequency of three times a month. The number of samples in this study adopted the theory proposed by Hair, Ringle, \& Sarstedt (2011). Where, the sample size is measured based on the number of question items on the research indicator then multiplied by five. The number of question items in this study were 35 items. Therefore, the minimum sample size in this study was 34 x 5 , namely 170 respondents. The sample obtained in this study was 202 respondents. The questionnaire was collected through an online survey, on Youtube users in Indonesia who are interested in culinary content. 
The data analysis method in this study uses Partial Least Squares - Structural Equation Model (PLS-SEM) to analyze the causal relationship between latent constructs and test the relationship to the hypothesis. PLS-SEM was chosen because the researchers developed a theory from pre-existing research models and were predictionoriented (Heir et al., 2011). The data analysis method is divided into two stages: separate assessments of the measurement model and the structural model. In the first stage, the data sample is checked for reliability and validity based on the measurement model. Measurement of reliability and validity will be carried out to see the stability of each research variable. In the second stage, the sample is assessed against each variable based on the structural model's estimates. Measurement model: Internal consistency reliability, determined by the value of composite reliability (CR), must be greater than 0.70 . Indicator reliability, which is determined by the loading factor indicator value, must be greater than 0.70. Convergent validity, which is determined by means of the average variance extracted (AVE) value which must be higher than 0.50. Structural model: The $\mathrm{R}^{2}$ value for endogenous latent variables in the structural model illustrates the magnitude of influence between variables. A value of 0.25 describes a weak influence, a value of 0.50 describes a moderate effect, while a value of 0.75 describes a strong influence. The bootstrapping test is used to assess the path coefficient's significance, with the minimum number of bootstraps being 5,000. The critical t-value in the two-tailed test used is 5\%, and the $\mathrm{t}$-value of alpha $5 \%$ is 1.9 .

\section{Results \& Discussions}

\subsection{Results}

Data on the demographic characteristics of respondents obtained are described in Table 1, which is dominated by women (59\%). Age is dominated by ages $18-25$ and $26-35$ years old $(86.14 \%$ ), who are millennials as most internet users. The education level is dominated by Bachelor degree (60\%). Employment is dominated by private employees $(46.04 \%)$. The marital status is predominantly single $(73.7 \%)$. Income is dominated by an average monthly income of IDR 5,000,000 - IDR 10,000,000 (44\%). The viewing time is predominantly 1-3 hours/day $(47.5 \%)$.

Table 1. Demographic Characteristics Of Respondents Characteristic

\begin{tabular}{|c|c|c|c|}
\hline Category & Characteristic & $\begin{array}{ll}\text { Number } & \text { of } \\
\text { Respondents } & \\
\end{array}$ & $\begin{array}{ll}\text { Percentage } & \text { of } \\
\text { Respondent } & \\
\end{array}$ \\
\hline \multirow{2}{*}{ Gender } & Male & 83 & $41.09 \%$ \\
\hline & Female & 119 & $58.91 \%$ \\
\hline \multirow{6}{*}{ Age } & $<18$ years old & 8 & $3.96 \%$ \\
\hline & $18-25$ years old & 88 & $43.56 \%$ \\
\hline & 26 - 35 years old & 86 & $42.57 \%$ \\
\hline & 36 - 45 years old & 13 & $6.44 \%$ \\
\hline & 46 - 55 years old & 5 & $2.48 \%$ \\
\hline & $>55$ years old & 2 & $0.99 \%$ \\
\hline \multirow{4}{*}{ Education } & Senior High School & 40 & $19.80 \%$ \\
\hline & D3 & 18 & $8.91 \%$ \\
\hline & $\mathrm{S} 1$ & 121 & $59.90 \%$ \\
\hline & $\mathrm{S} 2$ & 23 & $11.39 \%$ \\
\hline \multirow{5}{*}{ Profession } & Housewife & 6 & $2.97 \%$ \\
\hline & General Employee & 93 & $46.04 \%$ \\
\hline & Government Employee & 10 & $4.95 \%$ \\
\hline & Student/College Student & 66 & $32.67 \%$ \\
\hline & Entrepreneur & 27 & $13.37 \%$ \\
\hline \multirow{2}{*}{ Status } & Single & 149 & $73.76 \%$ \\
\hline & Married & 53 & $26.24 \%$ \\
\hline \multirow{3}{*}{ Income } & $<\operatorname{Rp} 5.000 .000$ & 38 & $18.81 \%$ \\
\hline & $\begin{array}{lll}\mathrm{Rp} & 5.000 .000 \\
10.000 .000 & -\end{array}$ & 89 & $44.06 \%$ \\
\hline & $\begin{array}{ll}\mathrm{Rp} & 10.000 .001\end{array}$ & 39 & $19.31 \%$ \\
\hline
\end{tabular}




\begin{tabular}{|c|l|l|l|} 
& 15.000 .000 & & \\
\cline { 2 - 4 } & $\begin{array}{l}\text { Rp 15.000,001 - } \\
20.000 .000\end{array}$ & 28 & $13.86 \%$ \\
\cline { 2 - 4 } & $>$ Rp 20.000.000 & 8 & $3.96 \%$ \\
\hline Watch Time & $<1$ hour/day & 91 & $45.05 \%$ \\
\hline $\begin{array}{c}\text { Watch } \\
\text { Time }\end{array}$ & $1-3$ hour/day & 96 & $47.52 \%$ \\
\cline { 2 - 4 } & $3-6$ hour/day & 15 & $7.43 \%$ \\
\hline
\end{tabular}

Measurement of validity and reliability tests was carried out to see the variables' stability in the study. The validity and reliability tests were determined by looking at the results of the convergent test and composite reliability. The results of the convergent test to determine the validity of the questionnaire items were assessed from the factor loading, which had to be more than 0.7, and the AVE value, which had to be more than 0.5, while to assess the reliability of the questionnaire items it was referred to the composite reliability value which had to be higher than 0.7. The calculation results for the loading factor, AVE, and CR values can be seen in Table 2.

After analyzing the convergent validity and composite reliability test results, an analysis of the results of the discriminant validity test is then carried out. The result of the discriminant validity test is the square root of the AVE value for each variable in the study. The discriminant validity value of a variable must be higher than its correlation value with other construct variables. If the discriminant validity value of a variable is higher than its correlation value with other construct variables, the variable can be said to be valid. Can be seen in Table 3 .

Tabel 2. Convergent Validity And Reliability

\begin{tabular}{|c|c|c|c|c|c|}
\hline Variable & Code & Mean & Loading Factor & AVE & $\mathbf{C R}$ \\
\hline \multirow{3}{*}{ Social Attractiveness } & SA 1 & 3.71 & 0.922 & \multirow{3}{*}{0.776} & \multirow{3}{*}{0.912} \\
\hline & SA 2 & 3.69 & 0.918 & & \\
\hline & SA 3 & 4.04 & 0.798 & & \\
\hline \multirow{2}{*}{$\begin{array}{l}\text { Physical } \\
\text { Attractiveness }\end{array}$} & PA 1 & 3.93 & 0.949 & \multirow{2}{*}{0.908} & \multirow{2}{*}{0.952} \\
\hline & PA 2 & 3.76 & 0.957 & & \\
\hline \multirow{4}{*}{ Attitude Homophily } & AH 1 & 4.25 & 0.744 & \multirow{4}{*}{0.615} & \multirow{4}{*}{0.824} \\
\hline & AH 2 & 4.22 & 0.712 & & \\
\hline & AH 3 & 4.09 & 0.846 & & \\
\hline & AH 5 & 4.37 & 0.708 & & \\
\hline \multirow{4}{*}{ Interactivity } & I 1 & 3.61 & 0.837 & \multirow{4}{*}{0.692} & \multirow{4}{*}{0.899} \\
\hline & I 2 & 3.42 & 0.832 & & \\
\hline & I 3 & 3.70 & 0.915 & & \\
\hline & I 4 & 3.83 & 0.735 & & \\
\hline \multirow{3}{*}{ Openness } & O 1 & 4.38 & 0.848 & \multirow{3}{*}{659} & \multirow{3}{*}{0.853} \\
\hline & $\mathrm{O} 2$ & 4.49 & 0.84 & & \\
\hline & O 3 & 4.41 & 0.744 & & \\
\hline \multirow{3}{*}{ Credibility } & C 1 & 3.71 & 0.873 & \multirow{3}{*}{0.767} & \multirow{3}{*}{0.908} \\
\hline & $\mathrm{C} 2$ & 4.14 & 0.901 & & \\
\hline & C 3 & 4.20 & 0.849 & & \\
\hline \multirow{4}{*}{ Para-social Interaction } & PSI 3 & 3.91 & 0.786 & \multirow{4}{*}{0.694} & \multirow{4}{*}{0.901} \\
\hline & PSI 4 & 3.72 & 0.889 & & \\
\hline & PSI 6 & 3.73 & 0.809 & & \\
\hline & PSI 7 & 3.77 & 0.845 & & \\
\hline \multirow{2}{*}{ Intention to Purchase } & PI 2 & 4.18 & 0.786 & \multirow{2}{*}{0.633} & \multirow{2}{*}{0.873} \\
\hline & PI 3 & 4.20 & 0.768 & & \\
\hline
\end{tabular}




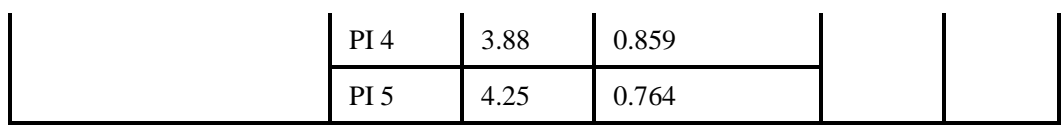

TABLE 3. Discriminant Validity

\begin{tabular}{|c|c|c|c|c|c|c|c|c|}
\hline Variable & 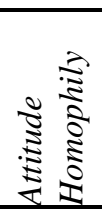 & 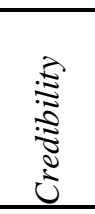 & 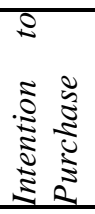 & 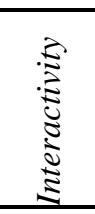 & 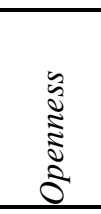 & 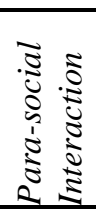 & 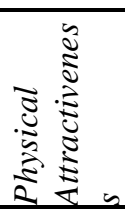 & 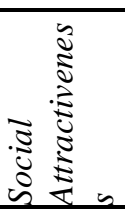 \\
\hline Attitude Homophily & 0.813 & & & & & & & \\
\hline Credibility & 0.301 & 0.77 & & & & & & \\
\hline $\begin{array}{ll}\text { Intention } & \text { to } \\
\text { Purchase } & \end{array}$ & 0.639 & 0.449 & 0.835 & & & & & \\
\hline Interactivity & 0.508 & 0.206 & 0.526 & 0.885 & & & & \\
\hline Openness & 0.569 & 0.521 & 0.566 & 0.417 & 0.9 & & & \\
\hline $\begin{array}{l}\text { Para-social } \\
\text { Interaction }\end{array}$ & 0.485 & 0.522 & 0.649 & 0.661 & 0.423 & 0.848 & & \\
\hline $\begin{array}{l}\text { Physical } \\
\text { Attractiveness }\end{array}$ & 0.441 & 0.452 & 0.459 & 0.488 & 0.406 & 0.716 & 0.957 & \\
\hline Social Attractiveness & 0.22 & 0.391 & 0.23 & 0.291 & 0.306 & 0.508 & 0.518 & 0.834 \\
\hline
\end{tabular}

\subsection{Hypothesis testing results}

In this study, the confidence level used was $95 \%$, so the t-statistic had to reach $>1.96$ and a p-value $<0.05$ where the hypothesis was accepted. The results of this hypothesis test can be seen in Table 4 . Table 4 describes the structural models that have been made. The hypothesis can be accepted if the t-statistic value reaches $>1.96$ and the p-value $<0.05$. From the test results in Table 4 , it can be concluded that hypotheses $1,2,3,4,7$, and 8 are accepted because the T-Stat value is greater than 1.96, and the P-value is smaller than 0.05. Meanwhile, hypotheses 5,6, and 9 were rejected because the P-value was greater than 0.05 and the T-Stat was smaller than 1.96.

TABLE 4. Hypothesis Results

\begin{tabular}{|l|l|l|l|l|l|}
\hline Hypothesis & Path & $\begin{array}{l}\text { Path } \\
\text { Coefficient }\end{array}$ & $\begin{array}{l}\boldsymbol{T} \text { - } \\
\text { Statistic }\end{array}$ & $\begin{array}{l}\text { P- } \\
\text { Values }\end{array}$ & Result \\
\hline H1 & $\begin{array}{l}\text { Para-Social Interaction -> Intention to } \\
\text { Purchase }\end{array}$ & 0.555 & 8.457 & 0 & Accepted \\
\hline H2 & Credibility -> Intention to Purchase & 0.187 & 2.412 & 0.018 & Accepted \\
\hline H3 & Physical Attractiveness -> Credibility & 0.395 & 5.819 & 0 & Accepted \\
\hline H4 & $\begin{array}{l}\text { Physical Attractiveness-> Para-social } \\
\text { Interaction }\end{array}$ & 0.409 & 6.066 & 0 & Accepted \\
\hline H5 & Attitude Homophily -> Credibility Para-social & 0.077 & 1.266 & 0.224 & Rejected \\
\hline H6 & $\begin{array}{l}\text { Attitude Homophily -> Pnteraction } \\
\text { In Panected }\end{array}$ \\
\hline
\end{tabular}

\begin{tabular}{|l|l|l|l|l|l|}
\hline H7 & Social Attractiveness -> Para-social Interaction & 0.174 & 3.675 & 0 & Accepted \\
\hline H8 & Interactivity -> Para-social Interaction & 0.364 & 5.721 & 0 & Accepted \\
\hline H9 & Openness -> Para-social Interaction & 0.010 & 0.217 & 0.832 & Rejected \\
\hline
\end{tabular}




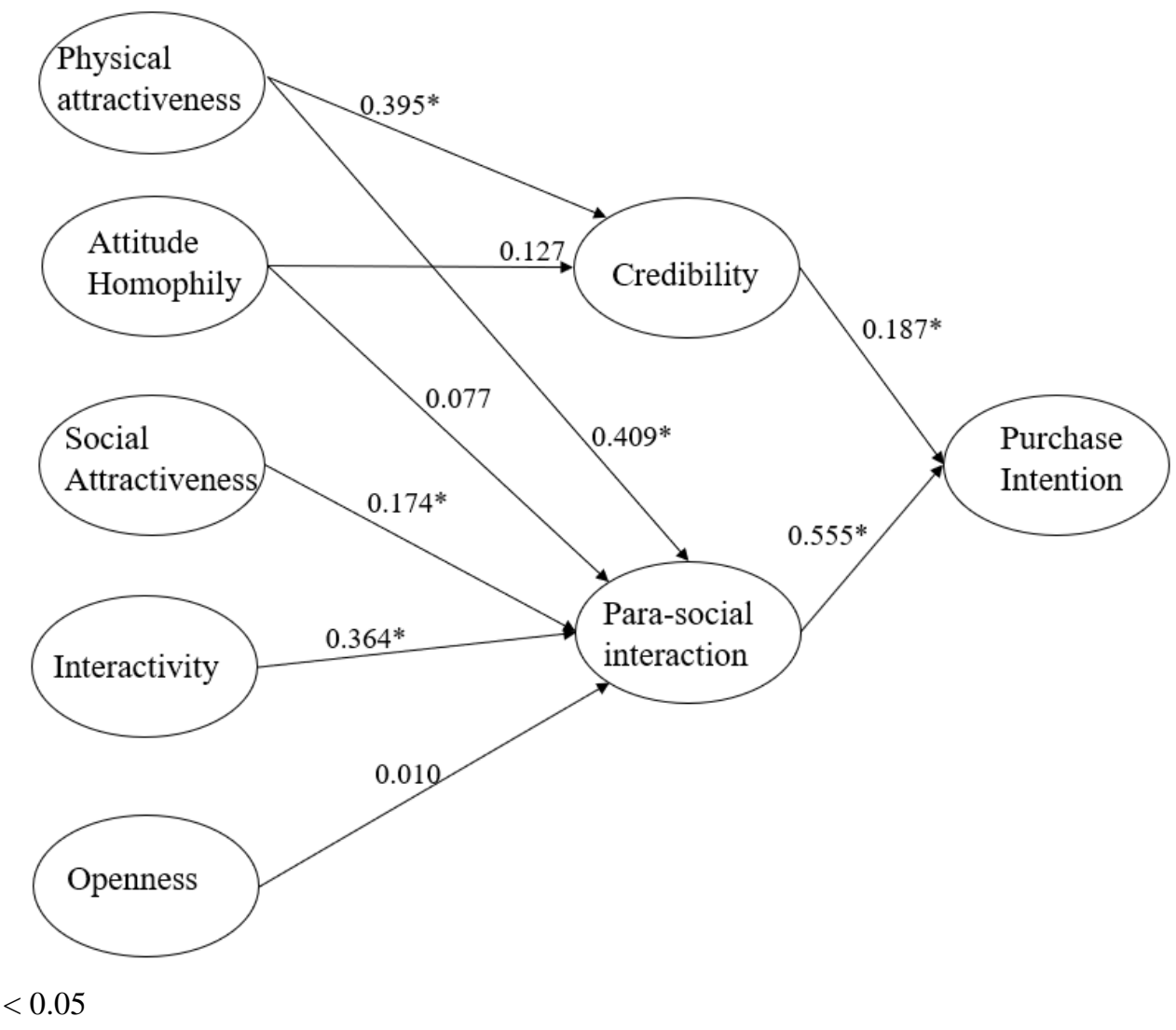

Figure 2. Structural Model

Referring to Figure 2. H1, H2, H3, H4, H7, and H8 are supported because the hypothesis shows positive Beta and P-values, which are less than 0.05. Meanwhile, H5, H6 (attitude homophily), and H9 (openness) act the opposite so that they are rejected from the structural model. From these results, it can be shown that almost all of the results support the hypothesis that has been made. Of all the independent variables studied, the physical attractiveness variable has the greatest influence compared to other variables with a beta value of 0.41 . Second, interactivity with a beta value of 0.36 . The variable that has the third-largest influence is social attractiveness with a beta value of 0.17 . Surprisingly, physical attractiveness did not have a significant impact on credibility or social interactions. Then, openness does not have a significant impact on parasocial interactions. Furthermore, the mediation variable, parasocial interaction, has a greater effect on purchase intention compared to food vlogger credibility.

\subsection{Discussions}

Physical attractiveness, interactivity, and social attractiveness influence parasocial interactions because the things that influence audiences to interact with food vloggers on YouTube are the audience first assessment of what they see from the physical attractiveness of food vloggers such as attractive appearance, face a beautiful or handsome face and the charisma of a food vlogger. According to Wise et al. (2012), the audience's interest in interacting with food vloggers on social media is also influenced by a large number of followers because a large number of friends and followers on social media illustrates the good personality of an influencer and good social relationships with followers which will affect the level of interaction of influencers with their followers. Furthermore, the thing that can affect parasocial interaction is the audience's interactivity based on the speed of the response by the food vlogger to the interactions the audience has on social media, which will make the audience feel more valued (Labrecque, 2014). Physical attractiveness influences credibility due to the audience's interest in the physical attractiveness of food vloggers; this makes the audience believe in the information conveyed by food vloggers about culinary. Trust will relate to perceptions of honesty from food vloggers, which can reflect a positive response to a food vlogger so that it can increase the assessment of credibility (Kefi \& Sokolova, 2018). Parasocial interaction and credibility influence purchase intention because a food vlogger who is considered to have good credibility by his followers can influence his follower's attitudes and behavior in buying products reviewed and recommended by the food vlogger. Furthermore, the more frequent interactions that occur between the audience and the food vlogger on social media, the closer the relationship between the food vlogger 
and the audience will be so that the audience will perceive food vloggers as a reliable source of information that can influence the audience's desire to buy the products suggested by food vlogger (Lee \& Watkins, 2016).

There are three hypotheses rejected in this study, namely homophily attitude, which does not affect social interaction and credibility, as well as openness, which does not affect parasocial interactions. Attitude homophily does not affect parasocial interactions and credibility because the assessment of credibility and parasocial interactions comes from the viewer's assessment of the food vlogger. The audience perceives this through what they see rst from the pro le or video displayed by the food vlogger, such as the appearance of the food they see review, the situation where they eat, the face of the food vlogger, and the appearance of the food vlogger on the YouTube channel. So, even though they do not have the same attitude homophily as the food vlogger, audiences will continue to interact and trust the food vlogger's information (Rushworth \& Djafarova, 2017). Furthermore, openness does not affect parasocial interactions because, based on the results of interviews, the ease of obtaining information in the digital era and the culinary information provided by food vloggers on social media is complete. Hence, making the audience feel that they do not need to interact with food vloggers to ask more clearly information provided by the food vlogger on his YouTube channel.

\section{Implications \& Suggestions Or Future Studies}

\subsection{Managerial Implications}

Currently, the culinary business is starting to move towards digital communication to promote its products and brands. Where, social media and food vloggers (influencers) are inevitable when planning a marketing strategy because video documentation made by food vloggers on their YouTube channel can form opinions and influence the attitudes and behavior of their followers, create advocacy, change references and purchase an interest in followers (Tinaprilla et al., 2019). The results of this study can be useful for marketers who will collaborate with food vloggers to introduce their brands and promote their culinary business. Marketers should collaborate with food vloggers who have physical attractiveness, namely food vloggers who always look attractive, have handsome or beautiful faces, and have a unique communication style. Second, collaborating with food vloggers who have social attractiveness, namely food vloggers who have a large following, have a close relationship with their followers. Third, collaborating with food vloggers who have high interactivity in responding to audiences' interactions in the comments' column quickly and efficiently.

This research is also useful for influencers (food vloggers) to strategize in creating content and collaborating with brands. Food vloggers must pay attention to factors that can influence audiences' assessment of credibility and factors that can enhance social interaction. For food vloggers, the first thing that must be considered is physical attractiveness because it is the first thing that will become the audience's consideration in choosing a food vlogger. Therefore, a food vlogger must always maintain his physical appearance so that he always looks attractive and must always be ready in front of the camera. Second, social attractiveness, having a large following on social media is important for food vloggers to build the impression that the audience sees that food vloggers have high social attractiveness (Wise et al., 2012). A food vlogger can look for unique culinary delights from an area, make interesting captions, use language that is easy for the audience to understand. So, it can attract audiences to subscribe to its YouTube channel. Also, a food vlogger must be able to create closeness with the audience by consistently posting videos every week because watching repeated videos or vlogs will increase intense interaction, which can make audiences feel that food vloggers like them. Third, to build good relationships and increase interaction with the audience, food vloggers can invite audiences to give opinions and provide culinary references in the comments column. However, food vloggers must have interactivity in responding to interactions made by the audience in the comments column quickly because it will make the audience feel more valued. Fourth, to attract cooperation with a culinary brand or business, a food vlogger must have credibility. A food vlogger can establish credibility by having extensive knowledge of food and beverage flavors, making food display attractive, providing honest reviews of the food or drink reviewed attractive physical appearance, and using a professional videographer to ensure the quality of the uploaded video is good to show that a food vlogger is an expert in the culinary field.

\subsection{Suggestions for Future Studies}

Due to limitations in the scope of the study, namely the minimal number of samples studied, further research can be carried out using a larger sample size to better describe the character of the population. Further research can also be carried out on Generation $\mathrm{Z}$ because Generation $\mathrm{Z}$ has begun to mature and take over control of the world from the millennial generation. Also, Generation $\mathrm{Z}$ is the generation that is more familiar with the internet and technology. Further research can also be carried out in different business industries because the different industries chosen as research objects can produce different research results. In this study, the culinary business has been used. Future research can use other business industries such as tourism to compare results and provide 
references on strategies to introduce, develop, and revive Indonesia's tourism industry, which was affected by the Covid-19 pandemic. Future studies can test other social media, which are trending among Indonesians. In this study, the social media YouTube has been used, and further research can examine other social media such as Tik Tok. According to Selular.id (2020), the increase in Tik Tok users in Indonesia is 30.7 million users with total downloads of 8.5 percent in July 2020; Indonesia is the fourth largest Tik Tok user country in the world so that it can be used as an opportunity for marketers as a new promotional media..

\section{References}

Auter, P. J. (1992). Psychometric: TV that talks back: An experimental validation of a parasocial interaction scale. Journal of Broadcasting \& Electronic Media, 36(2), 173-181.

Brown, W. J. (2015). Examining Four Processes of Audience Involvement with Media Personae: Transportation, Parasocial Interaction, Identification, and Worship. Journal of Communication Theory, 25(3), 259-283.

C.A. Onu, J Nwaulune, E.A. Adegbola, \& G. Nnorom. (2019). The Effect of Celebrity Physica Attractiveness and Trustworthiness on Customer Purchase Intention. Journal of Management Sciences Letters.

Carr, C. T., \& Hayes, R. A. (2015). Social media: Defining, developing, and divining. Atlantic Journal of Communication.

Colliander, J., \& Dahlen, M. (2011, March). Following the Fashionable Friend: The Power of Social Media Weighing Publicity Effectiveness of Blogs Versus Online Magazines. Journal of Advertising Research.

Djafarova, E., \& Rushworth, C. (2017). Exploring the credibility of online celebrities' Instagram profiles in influencing the purchase decisions of young female users. Journal of Computers in Human Behavior, 68, 1-7.

Eyal, K., \& Rubin, A. M. (2003). Viewer Aggression and Homophily, Identification, and ParaSocialRelationships with Television Characters. Journal of Broadcasting \& Electronic Media, 47(1), 77-98.

Fan, Y.-W., Miao, Y.-F., 2012. Effect of Electronic Word-Of-Mouth On Consumer Purchase Intention: The Perspective of Gender Differences. International Journal of Electronic Business Management 10(3), $175-181$.

Freeman, B., \& Chapman, S. (2007). Is "YouTube" telling or selling you something? Tobacco content on the YouTube video-sharing website. Tobacco Control, 16(3), 207-210.

Giles, D.C., 2002. Parasocial interaction: a review of the literature and a model for future research. Media Psychol. 4 (May), 279-305.

Gunawan, D.D., Huarng, K.-H., 2015. Viral effects of social network and media on consumers' purchase intention. J. Bus. Res. 68 (11), 2237-2241.

Hartmann, T., \& Goldhoorn, C. (2011). Horton and Wohl Revisited: Exploring Viewers' Experience of Parasocial Interaction. Journal of Communication, 61(6), 1104-1121.

Hair, Joe F., Ringle, Christian M., \& Sarstedt, Marko. (2011). PLS-SEM: Indeed a Silver Bullet. Journal of Marketing Theory and Practice, 19:2, 139-152.

Hui, T.X., (2017). The Effect of Source Credibility on Consumers' Purchase Intention in Malaysia Online Community. Journal of Arts \& Social Sciences 1(1), 12-20.

Hootsuite We are social. (2021, Jan 6). Indonesia Digital Repost 2020. Diakses dari https://andi.link/hootsuitewe-are-social-indonesian-digital-report-2020/.

Horton, D., \& Wohl, R. R. (1956). Mass communication and para-social interaction: Observations on intimacy at a distance. Psychiatry, 19, 215-229.

Kemp, S., (30 Januari 2019) Digital 2019: Global Internet Use Accelerates. Diakses dari https://wearesocial.com/blog/2019/01/digital-2019-global-internet-use-accelerates.

Khamis, S., Ang, L., \& Welling, R. (2016). Self-branding, 'micro-celebrity', and the rise of Social Media Influencers. Celebrity Studies, 8(2), 191-208.

Klassen, K.M., Borleis, E.S., Brennan, L., Reid, M., McCaffrey, T.A., Lim, M.S., 2018. What people "like": analysis of social media strategies used by food industry brands, lifestyle brands, and health promotion organizations on Facebook and Instagram. J. Med. Internet Res. 20 (6), e10227.

Kotler, Philip, and Kevin Lane Keller, (2012): Marketing Management, 14th Edition New Jersey: Pearson Prentice Hall, Inc.

Kusnandar, V. B. (2019, Mei 16). Pengguna Internet di Indonesia 2018 Bertambah 28 Juta. Diakses dari https://databoks.katadata.co.id/datapublish/2019/05/16/pengguna-internet-di-indonesia-2018-bertambah-28juta

Kusumaastuti, (2020). Pengaruh Pandemi Covid-19 terhadap Eksistensi Bisnis UMKM dalam mempertahankan Business Continuity Management (BCM). eJournal Administrasi Bisnis, 2020,8(3): 224-232.

Labrecque, L. I. (2014). Fostering Consumer-Brand Relationships in Social Media Environments: The Role of Parasocial Interaction. Journal of Interactive Marketing, 28(2), 134-148. doi:10.1016/j.intmar.2013.12.003

Lee, J.E., Watkins, B., 2016. YouTube vloggers' influence on consumer luxury brand perceptions and intentions. Journal of Business Research 
Lin, X., Spence, P.R., Lachlan, K.A., 2016. Social media and credibility indicators: the effect of influence cues. Comput. Hum. Behav. 63, 264-271.

Master. (2015, Juni 29). Apa sih vlog itu? Diambil kembali dari Sporttainment: www.loop.co.id/articles/apa-sihvlog-itu-kok-ngetren-banget-ya.

McMillan, Sally J. and Jang S. Hwang (2002), "Measures of Perceived Interactivity: An Exploration of the Role of Direction of Communication, User Control, and Time in Shaping Perceptions of Interactivity," Journal of Advertising, 31, 3, 29-42

McPherson, M., Smith-Lovin, L., \& Cook, J. M. (2001). Birds of a feather: Homophily in social networks. Annual Review of Sociology, 27, 415-444.

Oswald, D. L., Clark, E. M., \& Kelly, C. M. (2004). Friendship maintenance: An analysis of individual and dyad behaviors. Journal of Social and Clinical Psychology, 23(3), 413- 441.

Patrick Jonathan (21 Agustus 2019). Youtube Ungkap 2 Video Kesukaan Penonton Indonesia. Diakses dari https://www.cnnindonesia.com/teknologi/20190821190938-185-423530/youtube-ungkap-2-tipe-videokesukaan-penonton-indonesia.

Razak, N. I. A., \& Zulkifly, M. I. (2020). The impacts of food vlog attribute on para-social interaction and customers' response behaviors. Journal of Tourism, Hospitality \& Culinary Arts, 12(1), 435-445.

Rubin, R. B., \& McHugh, M. P. (1987). Development of parasocial interaction relationships. Journal of Broadcasting \& Electronic Media, 31, 279e292.

Sakib, M. N., Zolfagharian, M., \& Yazdanparast, A. (2019). Does parasocial interaction with weight loss vloggers affect compliance? The role of vlogger characteristics, consumer readiness, and health consciousness. Journal of Retailing and Consumer Services. doi:10.1016/j.jretconser.2019.01.002.

Selular.id. (2021, Jan 6). Meski Indonesia Salah Satu Pengguna TikTok Terbesar, ByteDance Pilih Singapura Sebagai SasaranInvestasi. Diakses dari https://selular.id/2020/09/meski-indonesia-salah-satu-penggunatiktok-terbesar-bytedance-pilih-singapura-sebagai-sasaran-investasi

Sooyoung Choi, Insin Kim, Kyungsoo Cha, Yong-Kun Suh \& Keun-Hyung Kim (2019) Travelers' parasocial interactions in online travel communities, Journal of Travel \& Tourism Marketing, 36:8, 888-904.

Sokolova, K., \& Kefi, H. (2019). Instagram and YouTube bloggers promote it, why should I buy it? How credibility and parasocial interaction influence purchase intentions. Journal of Retailing and Consumer Services.

Song, J. H., \& Zinkhan, G. M. (2008). Determinants of Perceived Web Site Interactivity. Journal of Marketing, $72(2), 99-113$.

Sweetser, K. D., \& Metzgar, E. (2007). Communicating during crisis: Use of blogs as a relationship management tool. Public Relations Review, 33(3), 340-342.

Tariq, M. I., Nawaz, M. R., Nawaz, M. M. and Butt, H. A. (2013), "Customer perceptions about branding and purchase intention: a study of FMCG in an emerging market" Journal of Basic and Applied Scientific Research", Vol. 3 No.2, pp. 340-347.

Tinaprilla, N., Sumarwan, U., and Hermanda, A. (2019). The Effect of Social Media Influencer on Brand Image, Self-Concept, and Purchase Intention. Journal of Consumer Sciences, 4(2), 76-89.

Uma, Sekaran \& Roger, Bougie. (2013). Research Methods for Business. 7th ed. Chichester, West Sussex, United Kingdom: John Wiley \& Sons.

Wathen \& Burkell. (2002). Believe it or not: Factors influencing credibility on the Web. Journal of the American Society for Information Science and Technology, 53(2), 134-144.

Wise, Kim, Tandoc \& Hong (2012). The Real You? The Role of Visual Cues and Comment Congruence in Perceptions of Social Attractiveness from Facebook Profiles. CYBERPSYCHOLOGY, BEHAVIOR, AND SOCIAL NETWORKING Volume 15, Number 7, 2012 Mary Ann Liebert, Inc.

Wu, P., Yeh, G., \& Hsiao, C. (2011). The effect of store image and service quality on brand image and purchase intention for private label brands. Australasian Marketing Journal, 19(1), 30-39.

Zhuang, Jiahui. (2018). Engaging in Celebrity's Social Media Page with the Mediation of Parasocial Interaction and Parasocial Relationship. Graduate Theses and Dissertations.

\section{APPENDIX}

\begin{tabular}{llc}
\hline \multicolumn{1}{c}{ Variable } & \multicolumn{1}{c}{ Items } & Kode \\
\hline Social & I thought that vlogger X could become my friend. & SA1 \\
Attractiveness & I thought that vlogger X liked me. & SA2 \\
& I want to have a conversation with the vlogger. & SA3 \\
\hline Physical & I find vlogger X physically attractive. & PA1 \\
Attractiveness & I thought that vlogger X was pretty or handsome. & PA2 \\
& Vlogger x has an interesting style of speech. & PA3 \\
\hline
\end{tabular}




\begin{tabular}{|c|c|c|}
\hline \multirow{5}{*}{$\begin{array}{l}\text { Attitude } \\
\text { Homophily }\end{array}$} & Vlogger $\mathrm{X}$ has the same taste of food like me. & AH1 \\
\hline & Vlogger $\mathrm{X}$ has one thought with me about culinary. & $\mathrm{AH} 2$ \\
\hline & Vlogger X behaves just like me. & AH3 \\
\hline & Vlogger X treats other people like me. & $\mathrm{AH} 4$ \\
\hline & Vlogger $\mathrm{X}$ has a lot in common with me & AH5 \\
\hline \multirow[t]{4}{*}{ Interactivity } & Vlogger X will reply if I send a message. & I1 \\
\hline & Vlogger X will respond to me quickly or efficiently. & I2 \\
\hline & Vlogger X allowed me to communicate in person. & I3 \\
\hline & Vlogger X will listen to what I have to say about culinary & 14 \\
\hline \multirow[t]{3}{*}{ Openness } & Vlogger $\mathrm{X}$ is open to sharing information. & $\mathrm{O} 1$ \\
\hline & Vlogger X keeps me up to date with the latest information. & $\mathrm{O} 2$ \\
\hline & Vlogger X does not hold or cover information. & $\mathrm{O} 3$ \\
\hline \multirow[t]{4}{*}{ Credibility } & I consider vlogger $\mathrm{X}$ an expert in his field. & $\mathrm{C} 1$ \\
\hline & I consider vlogger $\mathrm{X}$ to be right for the job. & $\mathrm{C} 2$ \\
\hline & I consider vlogger $\mathrm{X}$ to be trusted in delivering. & $\mathrm{C} 3$ \\
\hline & I assume vlogger $\mathrm{X}$ cares about his followers & $\mathrm{C} 4$ \\
\hline \multirow{7}{*}{$\begin{array}{l}\text { Para-social } \\
\text { Interaction }\end{array}$} & I look forward to watching vlogger X on his YouTube channel. & PSI1 \\
\hline & If the $\mathrm{X}$ collaboration vlogger on another YouTube channel, I will watch it. & PSI2 \\
\hline & When I watch vlogger X, I feel like I'm part of the group. & PSI3 \\
\hline & I thought vlogger X was like an old friend. & PSI4 \\
\hline & I want to meet the vlogger $\mathrm{X}$ in person. & PSI5 \\
\hline & $\begin{array}{l}\text { If there's an article about vlogger } \mathrm{X} \text { in a newspaper or magazine, I'll read it. } \\
\text { vlogger } \mathrm{X} \text { makes me comfortable, like me with my friends. }\end{array}$ & PSI6 \\
\hline & & PSI7 \\
\hline \multirow[t]{5}{*}{$\begin{array}{l}\text { Purchase } \\
\text { Intention }\end{array}$} & $\begin{array}{l}\text { When vlogger } \mathrm{X} \text { shows how he feels about a product, it helps me decide between } \\
\text { buying that product. }\end{array}$ & PI1 \\
\hline & I will buy products promoted by vlogger $\mathrm{X}$ in the future. & PI2 \\
\hline & I will encourage the people closest to me to buy products promoted by vlogger X. & PI3 \\
\hline & $\begin{array}{l}\text { I would choose to buy a product that vlogger } \mathrm{X} \text { collaborates with, even if the } \\
\text { competitor's price is cheaper. }\end{array}$ & \\
\hline & $\begin{array}{l}\text { When a new product is collaborated or promoted by vlogger } \mathrm{X} \text {, then I will be } \\
\text { interested in buying. }\end{array}$ & PI4 \\
\hline
\end{tabular}

